\title{
Complex coacervates between bovine serum albumin and anionic polysaccharides: formation and characterization
}

\section{Complexos coacervados entre albumina do soro bovino e polissacarídeos aniônicos: formação e caracterização}

\author{
Lorena Oliveira Ferreira ${ }^{1}$, Monique Barreto Santos ${ }^{2 *}$ (1), Edwin Elard Garcia-Rojas ${ }^{1,2}$ \\ ${ }^{1}$ Universidade Federal Fluminense (UFF), Departamento de Engenharia de Agronegócios, \\ Volta Redonda/RJ - Brasil \\ ${ }^{2}$ Universidade Federal Rural de Rio de Janeiro (UFRRJ), Instituto de Tecnologia, Departamento de Tecnologia de \\ Alimentos, Seropédica/RJ - Brasil
}

${ }^{*}$ Corresponding Author: Monique Barreto Santos, Universidade Federal Rural de Rio de Janeiro (UFRRJ), Instituto de Tecnologia, Departamento de Tecnologia de Alimentos, Rodovia BR 465, km 07, s/n, CEP: 23890-000, Seropédica/RJ - Brasil, e-mail: moniquebarretomedvet@yahoo.com.br

Cite as: Ferreira, L. O., Santos, M. B., \& Garcia-Rojas, E. E. (2021). Complex coacervates between bovine serum albumin and anionic polysaccharides: formation and characterization. Brazilian Journal of Food Technology, 24, e2021070. https://doi.org/10.1590/1981-6723.07021

\begin{abstract}
The comparative study regarding complexes coacervated between Bovine Serum Albumin (BSA) and different polysaccharides, Pectin (PEC) and Gum Acacia (GA), was carried out by evaluating the influence of different ratios (protein:polysaccharide) and sodium chloride $(\mathrm{NaCl})$ concentrations on turbidity and zeta potential. The BSA:PEC complexes were formed in a 10:1 ratio whereas BSA:GA at 3:1. The complexation pH showed different behavior, BSA: PEC complexes exhibited maximum turbidity in a wide pH range (4.9 to 1.5 ), while BSA: GA had maximum turbidity at $\mathrm{pH}$ 3.5. The increase in the concentration of $\mathrm{NaCl}$ negatively influenced the complexation. The $\mathrm{NaCl}$ concentration of $0.40 \mathrm{~mol} \mathrm{~L}^{-1}$ suppressed the interaction in BSA:PEC (10:1) and reduced the range formation of BSA:GA (3:1). The Fourier Transform Infrared (FTIR) demonstrated the participation not only of electrostatic interactions, but also of hydrogen bonds in the complexation. This initial study elucidated fundamental aspects about the formation of coacervate complexes between BSA:GA/PEC that assist in directing its application in food products especially, in acidic matrices $(\mathrm{pH} \sim 4.0)$ as well as with low concentration of salts, in view of the effect of $\mathrm{pH}$ on maximum formation and sensitivity to $\mathrm{NaCl}$. These complexes can be added directly to products in order to add nutritional value or even be used as a new matrix for the encapsulation of bioactive compounds.
\end{abstract}

Keywords: Gum acacia; Pectin; Whey protein; BSA; FTIR; Encapsulation.

\section{Resumo}

O estudo comparativo de complexos coacervados entre albumina sérica bovina (BSA) e diferentes polissacarídeos, pectina (PEC) e goma acácia (GA), foi realizado avaliando-se a influência de diferentes razões (proteína:polissacarídeo) e concentrações de cloreto de sódio $(\mathrm{NaCl})$ na turbidez e no potencial zeta. Os complexos BSA:PEC foram formados na proporção 10:1, enquanto os de BSA:GA, na proporção 3:1. O pH de complexação apresentou comportamento 
diferenciado, complexos BSA:PEC exibiram máxima turbidez em uma ampla faixa de $\mathrm{pH}(4,9$ a 1,5), enquanto complexos BSA:GA tiveram turbidez máxima em pH 3,5. O aumento da concentração de $\mathrm{NaCl}$ influenciou negativamente a complexação, com a concentração de $\mathrm{NaCl}$ de $0,40 \mathrm{~mol} \mathrm{~L}^{-1}$ capaz de suprimir a interação em BSA:PEC (10:1) e reduzir a faixa de formação de BSA:GA (3:1). A espectroscopia de infravermelho com transformada de Fourier (FTIR) demonstrou a participação não apenas de interações eletrostáticas, mas também de ligações de hidrogênio na complexação. Este estudo inicial elucidou aspectos fundamentais sobre a formação de complexos coacervados entre BSA:GA/PEC que ajudam a direcionar sua aplicação em produtos alimentícios, especialmente em matrizes ácidas e com baixa concentração de sais, tendo em vista o pH máximo de formação $(\mathrm{pH} \sim 4,0)$ e a sensibilidade ao $\mathrm{NaCl}$. Esses complexos podem ser adicionados diretamente em produtos, a fim de agregar valor nutricional ou ainda serem utilizados como uma nova matriz para o encapsulamento de compostos bioativos.

Palavras-chave: Goma acácia; Pectina; Proteína de soro; BSA; FTIR; Encapsulação.

\section{Introduction}

The interaction between biopolymers is unstable and susceptible to the phenomenon of phase separation. This separation may occur due to thermodynamic incompatibility (segregation), as well as to the predominance of charge repulsion or complexation (complex coacervation), when there is a predominance of attraction between oppositely charged biopolymers (Souza et al., 2013; Kruif \& Tuinier, 2001; Tolstoguzov, 1991). Coacervation is defined by the International Union of Pure and Applied Chemistry (1997), as being a colloidal separation of systems in two liquid phases, because after the interaction in which a liquid phase is formed, without polymers and another one rich in polymer and electrically neutral, it is stabilized mainly by electrostatic interaction. Because it occurs through opposite charges, complex coacervation is influenced by intrinsic factors, such as charge density and distribution of its reaction groups and extrinsic factors such as $\mathrm{pH}$, temperature, ionic strength, proportion and concentration of biopolymer (Souza et al., 2013; Kruif \& Tuinier, 2001).

Complex coacervates have potential applications in the food and pharmaceutical industry, such as film making (Silva et al., 2018), emulsion stabilization (Bago Rodriguez et al., 2018) and protein purification (Souza et al., 2018b; Yang et al., 2020). However, the main application of coacervate complexes is related to the encapsulation and controlled delivery of bioactive compounds sensitive to environmental conditions (Eghbal \& Choudhary, 2018; Santos et al., 2021). The technique stands out for its high encapsulation efficiency (up to 99\%), low processing cost, and for not using chemical reagents and high temperatures (Souza et al., 2013; Timilsena et al., 2019). However, in order for these complexes to be applied in food systems, a detailed study of their behavior in relation to the variation of $\mathrm{pH}$, temperature and salt concentration is necessary (Dickinson, 2008).

Coacervate complexes can be obtained from numerous polyelectrolytes, mainly biopolymers such as proteins and polysaccharides, as they are biocompatible, biodegradable and non-toxic (Silva \& Andrade, 2009). Whey is an excellent source of protein, although it is part of the scenario of biofunctional products and of high nutritional value, it has still been discarded by some dairy industries (Ganju \& Gogate, 2017). One of the most well-characterized whey proteins is Bovine Serum Albumin (BSA), globular, consisting of 582 amino acid residues, $66.62 \mathrm{kDa}$ molar mass and isoelectric point of 4.7 (Zhao et al., 2009)

Among the polysaccharides used in the coacervation process are Pectin (PEC) and Gum Acacia (GA). The first one is associated with a structural polysaccharide that confers rigidity to the cell wall of vegetables being used in the food industry for its gelling, thickening and stabilizing properties. It differs by the degree of esterification being low methyl $(<50 \%)$ and high methyl $(>50 \%)$. The degree of esterification influences the structure, interaction, and properties of PEC. It has pKa between $2.0 \sim 3.0$ and molar mass of 70 to $140 \mathrm{kDa}$ (Muhoza et la., 2019). The second is related to an exudate of trees marketed for more than 5,000 years, has pKa 2.5 and molecular weight $350 \mathrm{kDa}$. It has no odor, taste, and color is considered a complex anionic 
polysaccharide, because it has a protein fraction responsible for its emulsifying property (Liu et al., 2009; Islam et al., 1997; Anvari et al., 2015).

Previous studies (Vinayahan et al., 2010; Li et al., 2012; Ru et al., 2012) have demonstrated the formation of complexes between these biopolymers (BSA, PEC and GA), however, information regarding the chemical composition and chemical bonds involved in the formation of these complexes are still rare in the literature.

This study aimed to study and compare the influence of $\mathrm{pH}$, ionic strength and ratio (protein:polysaccharide) on the formation of coacervate complexes obtained from BSA and PEC/GA, for later application in food products and characterize their formation through Fourier Transform Infrared spectroscopy (FTIR spectroscopy).

\section{Material and methods}

\subsection{Materials}

The PEC from citrus peel (Galacturonic acid $>74 \%$ ) and degrees of esterification $>67 \%$, GA from acacia tree and BSA ( $\geq 96 \%$ pure) were purchased from Sigma Chemicals (St. Louis, USA). Sodium chloride $(\mathrm{NaCl})$, hydrochloric acid $(\mathrm{HCl})$ and sodium hydroxide $(\mathrm{NaOH})$ were purchased from VETEC ${ }^{\circledR}$ Ltda, (Rio de Janeiro, Brazil). The water used was of ultrapure quality (Gehaka-Master P \& D - Brazil), with a conductivity of $0.05 \mu \mathrm{S} / \mathrm{cm}$.

\subsection{Preparation of complexes}

The polysaccharide concentration was set at $0.1 \%(\mathrm{w} / \mathrm{v})$ and BSA varied in five ratios $(1: 1,2: 1,3: 1,5: 1$, 10:1). To determine the effect of $\mathrm{NaCl}$, five concentrations of $\mathrm{NaCl}\left(0.0,0.01,0.05,0.1\right.$ and $\left.0.4 \mathrm{~mol} \mathrm{~L}^{-1}\right)$ were used. The materials were weighed using an analytical balance mod.B-TEC-210 ${ }^{\mathrm{a}}$ (Tecnal, Brazil) and had an uncertainty of $\pm 0.0001 \mathrm{~g}$. The solutions were solubilized with the aid of a magnetic stirrer NT101 (Nova Tecnica, Brazil) for three hours at room temperature $\left(25^{\circ} \mathrm{C}\right)$. For further turbidimetric titration, the $\mathrm{pH}$ of the solutions was previously adjusted to $\mathrm{pH} 7.0$ with sodium hydroxide $(\mathrm{NaOH})$ and with the aid of a bench pH meter mPA-210 (Tecnopon, Brazil) (Gulão et al., 2014).

\subsection{Turbidimetric titration}

The transmittance of the samples was measured with a UV-Vis spectrophotometer (Libra S12, Biochrom, England) at a wavelength of $400 \mathrm{~nm}$ using a glass cuvette with $1 \mathrm{~cm}$ optical path. The equipment was calibrated for $100 \%$ transmittance $(\mathrm{T}$ ) with ultrapure water and turbidity defined as $100-\% \mathrm{~T}$ (Souza et al., 2013).

The solution containing the defined protein:polysaccharide ratio and its respective $\mathrm{NaCl}$ concentration had its $\mathrm{pH}$ adjusted from 7.0 to $1.5 \mathrm{using} \mathrm{HCl}$ of different concentrations $\left(0.5,1\right.$ and $\left.1.5 \mathrm{~mol} \mathrm{~L}^{-1}\right)$ and $\mathrm{NaOH}\left(0.25 \mathrm{~mol} \mathrm{~L}^{-1}\right)$, with the aid of a magnetic stirrer and benchtop $\mathrm{pH}$ meter. Aliquots were then taken to measure the transmittance value. All titrations were performed at room temperature $\left(\sim 25^{\circ} \mathrm{C}\right)$ in triplicate.

\subsection{Potential - Zeta (ろ)}

Zetasizer Nano-ZS (Malvern Instruments, Worcestershire, UK) was used to determine the potential- $\zeta$ of protein:polysaccharide ratios, and of isolated proteins and polysaccharides. Initially, samples $(10 \mathrm{~mL})$ at $0.1 \%(\mathrm{w} / \mathrm{w})$ were added to a MPT-2 titrator (Malvern Instruments, Worcestershire, UK) containing $0.5 \mathrm{~mol}$ $\mathrm{L}^{-1} \mathrm{HCl}$ and $0.25 \mathrm{NaOH}$ solutions and $0.025 \mathrm{~mol} \mathrm{~L}^{-1}$. The titration was done between $\mathrm{pH} 2.0$ and 7.0 , in the range of $0.5 \pm 0.1$. The potencial- $\zeta$ was calculated based on the mathematical model of Smoluschwsky and the analysis was performed at room temperature $\left(\sim 25^{\circ} \mathrm{C}\right)$ in triplicate. 


\subsection{Fourier Transform Infrared (FTIR) spectroscopy}

Infrared spectra were obtained from the BSA, PEC, GA and lyophilized complex coacervations (Terroni, Enterprise I, Brazil) at the defined ratio. The analyzes were performed using the FTIR spectrophotometer Vertex 70 (Bruker, Germany) read in the range between 4000 to $500 \mathrm{~cm}^{-1}$.

\section{Results and discussions}

\subsection{Effect of $\mathrm{pH}$ and ratio on the formation of coacervated complexes}

The formation of the protein: polysaccharide complexes was verified by the variation of turbidity as a function of $\mathrm{pH}$ as well as the ratio between BSA: PEC (Figure 1a) and BSA: GA (Figure 1b). The initial pH of the solution was 7.0 and the slow addition of $\mathrm{HCl}$ reduced the $\mathrm{pH}$ to 1.5. During the titration and formation of the coacervate complexes between BSA:PEC (Figure 1a) three distinct turbidity regions, known as transition regions $\left(\mathrm{pH}_{\mathrm{c}}, \mathrm{pH}_{\varnothing 1}\right.$ and $\left.\mathrm{pH}_{\varnothing 2}\right)$, were found. For all the studied reasons, the turbidity values remained very low, i.e., practically constant between $\mathrm{pH} 7.0$ and 6.0, indicating the polymers presented in the soluble form. Between $\mathrm{pH} 6.0$ and near $\mathrm{pH} 5.0$ a gradual increase of the turbidity was observed, being denominated $\mathrm{pHc}$. This point $\left(\mathrm{pH}>\mathrm{pH}_{\mathrm{c}}\right)$ indicates the beginning of the formation of the soluble complexes through non-covalent attractions between the polymers (Gulão et al., 2014; Weinbreck et al., 2003). These soluble complexes are formed at a $\mathrm{pH}$ above the isoelectric point (pI) of the protein, with the presence of weak electrostatic interaction and high net load among biopolymers (Ru et al., 2012; Jones et al, 2009). It could be found that for different reasons different $\mathrm{pH}_{\mathrm{c}}$ are found. Possibly, this behavior is due to the equilibrium of charges between the polymers that occurs at different pHs owing to the difference of loads present in each system.
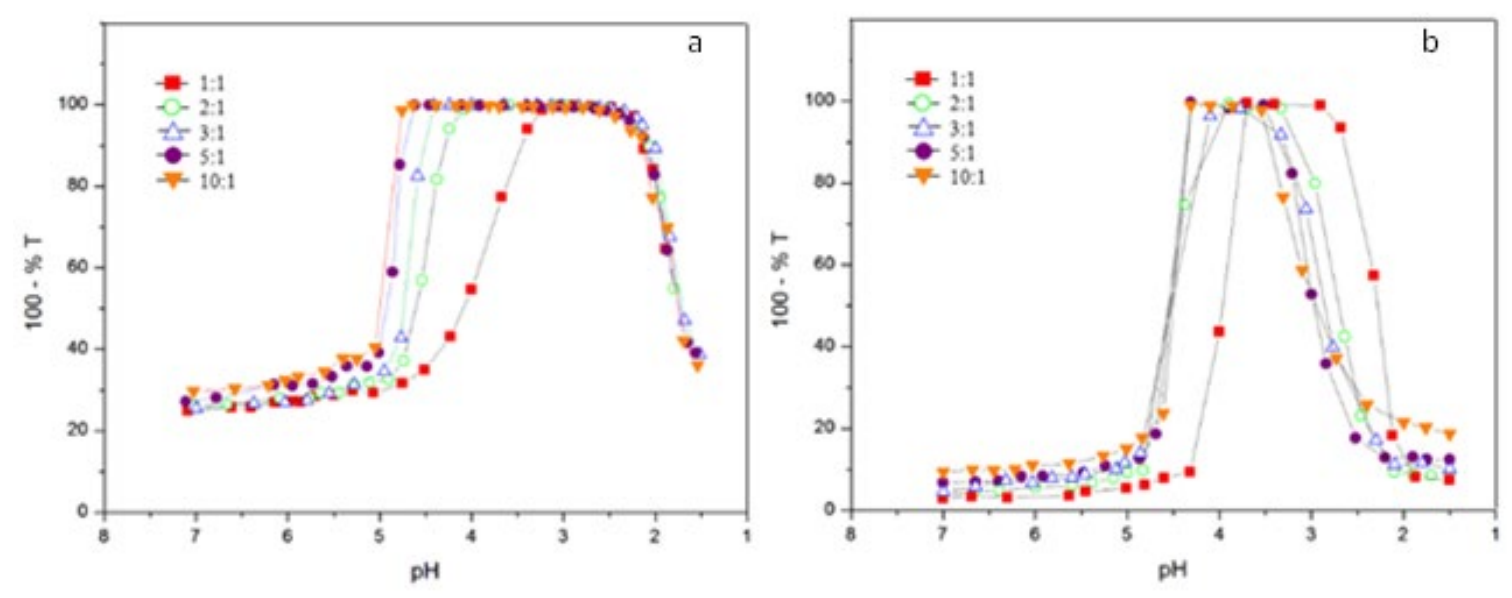

Figure 1. Turbidity (100 - T\%) versus $\mathrm{pH}$ of a system containing (a) BSA:PEC and (b) BSA:GA in different ratios.

From $\mathrm{pH} 5.0$ to $\mathrm{pH} 4.5$, near the isoelectric point of BSA $(\sim 4.7)$, there was a fast increase in turbidity $\left(\mathrm{pH}_{\varnothing 1}\right)$. This phase is characterized by the appearance of the coacervate phase, where the polysaccharide has negative charges and the protein positive charges, occurring electrostatic interaction and formation of insoluble complexes (Turgeon et al., 2003). Being close to $\mathrm{pH} 4.5$, except for the ratio 1:1 that only occurred near $\mathrm{pH}$ 3.0, the turbidity presented its maximum value making the solution look completely cloudy. The increased turbidity indicated the formation of a seemingly stable colloidal suspension of biopolymers sufficient to promote light scattering (Jones \& McClements, 2010). As observed in the results presented in Figure 1a, the $\mathrm{pH}$ maximum for BSA:PEC was achieved in a pH range (4.5 to 2.0), as well as also reported by Souza et al. (2018a), for complexes coacervated between PEC and lysozyme. This region represents a large interval for the application of these complexes in different food matrices. 
At $\mathrm{pH} 2.0$ low turbidity values indicated the beginning of the dissociation of the biopolymers and in $\mathrm{pH} 1.5$, the solution became totally transparent indicating the end of the complexation, being known as $\mathrm{pH}_{\varnothing 2}$. At this $\mathrm{pH}, \mathrm{PEC}$ (pKa $2.5 \sim 3.5$ ) lost much of its negative charge, promoting weaker electrostatic bonds and solubilizing the complexes formed previously. Similar $\mathrm{pH}$ transitions in the formation of complexes between BSA and Sugar Beet Pectin (SBP) were described by Li et al. (2012).

Previous studies have shown that the turbidity of an isolated PEC solution remains close to zero over the entire $\mathrm{pH}$ range ( 7.0 to 1.5 ) indicating that $\mathrm{PEC}$ does not form aggregates that can disperse light and interfere with turbidimetric analysis (Jones et al., 2009). Likewise, it has been demonstrated in the literature that BSA does not form aggregates at this $\mathrm{pH}$ range (Santos et al., 2018). Thus, it could be concluded that the observed turbidity was directly related to the formation of the complexes.

When analyzing Figure 1a, different ratios resulted in displacements of $\mathrm{pH}_{\varnothing 1}$. At the lowest ratio studied (1:1), we observed a very marked displacement at $\mathrm{pH}_{\varnothing 1}$, reducing the $\mathrm{pH}_{\max }$ range. In the ratios above 1:1 a wide range of formation was verified with the highest formation range observed in the ratio (10:1), due to the displacement of $\mathrm{pH}_{\varnothing 1}$. This dependence of $\mathrm{pH}_{\varnothing 1}$ for different reasons was verified by Muhoza et al. (2019) with gelatin and High-Methoxylated Pectin (HMP) where minor reasons shifted the formation of complexes to a lower $\mathrm{pH}$.

In the higher ratios (5:1 and 10:1), the interaction force between the protein and the polysaccharide was strong enough to virtually suppress the formation of soluble complexes $\left(\mathrm{pH}_{\mathrm{c}}\right)$, resulting in rapid increase in turbidity and insoluble complex formation $\left(\mathrm{pH}_{\varnothing 1}\right)$. By means of the turbidity variation analyzed in Figures 1a, it could be concluded that the turbidity was larger and more comprehensive in the 10:1 ratio of BSA:PEC. According to the literature, the best formation ratio is related to the load balancing of the biopolymers. Li et al. (2012) found that the best ratio between BSA and SBP was 8:1. Ru et al. (2012) studied the rheological behavior of complexes between BSA:PEC and found that maximum shear modulus is observed in the 10:1 ratio. According to the authors this could suggest that the density of the positive charge on BSA was approximately equal to that of the negative charges on PEC, and their interaction was almost at a maximum. In contrast, Muhoza et al. (2019) found the 3:1 ratio for complex coacervates formed between a high molecular weight fibrous protein, gelatin, and HMP, reinforcing that the biopolymer ratio for coacervation is achieved from load balancing.

For the BSA:GA systems (Figure 1b), a first region between $\mathrm{pH} 7.0$ and $5.5\left(\mathrm{pH}>\mathrm{pH}_{\mathrm{c}}\right.$ ) was found where the polymers were in the soluble form, thus verified by the turbidity close to zero (Lv et al., 2014; Aryee \& Nickerson, 2012). In fact, during titration and $\mathrm{pH}$ reduction, the protein begins to assume a positive charge, and near $\mathrm{pH} 5.0$ a gradual increase of the turbidity is observed, this $\mathrm{pH}$ being denominated as $\mathrm{pH}_{\mathrm{c}}$. From the $\mathrm{pH} 4.5$ near the isoelectric point of the protein there was an abrupt increase of the turbidity $\left(\mathrm{pH}_{\varnothing 1}\right)$ and around the $\mathrm{pH} 3.5$ the turbidity presented its maximum value. At $\mathrm{pH} 2.5$ low turbidity values indicated the start of the dissociation of the biopolymers and at $\mathrm{pH} 2.0$ the end of the complexation $\left(\mathrm{pH}_{\varnothing 2}\right)$ because GA had few negative charges. As observed in the results, the BSA: GA complexes showed a maximum $\mathrm{pH}$ for each ratio and not a maximum $\mathrm{pH}$ range as verified for the BSA: PEC complexes. This behavior limits its application to specific $\mathrm{pH}$ conditions.

Previous studies by Aryee \& Nickerson (2012) have shown that the turbidity of an isolated GA solution remains close to zero over the entire $\mathrm{pH}$ range (7.0 to 1.5) indicating that GA does not form aggregates that can disperse the light. The occurrence of complexation was previously reported for pea proteins (PPI) and GA (Liu et al., 2009) and ovalbumin and GA (Girard et al., 2003) and a peak near pH 3.5 was found.

As for PEC, the ratio of protein: polysaccharide ( $r$ ) mass had a great impact on the formation of complexes between BSA and GA. In the ratio 1:1 the values of $\mathrm{pH}_{\mathrm{c}}$ and $\mathrm{pH}_{\varnothing 1}$ moved considerably suggesting that the interactions were significantly reduced due to the low protein content. The ratios of 3:1 to 10:1 showed similar values of $\mathrm{pH}_{\mathrm{c}}$ and $\mathrm{pH}_{\varnothing 1}$. These results could suggest that the best characteristic associated with the interaction between BSA and GA was that of 3:1, because it is assumed that in this ratio the polysaccharide 
became saturated with protein chains and in larger ratios the proteins were in excess, not influencing the formation of coacervate complexes (Liu et al., 2009; Aryee \& Nickerson, 2012). The reasons found by Niu et al. (2014) for complexes formed between Ovalbumin and GA and by Liu et al. (2009) for PPI and GA was $2: 1$ and $1: 1$, respectively.

In a turbidimetric study and by dynamic light scattering, Vinayahan et al. (2010) verified the formation of insoluble complexes in ratio 2 at $\mathrm{pH}$ 4.7. Different results may be related to the use of slow acidification achieved by GDL. In the same study, the analysis regarding Isothermal Titration Calorimetry (ITC), revealed that the complexation between $\mathrm{pH} 3.0$ and 4.0 would consist of 60 molecules of BSA per GA molecule, whereas at $\mathrm{pH} 5.0$ of 10 to 1 .

Figure 2 illustrates solutions containing BSA:PEC (10:1) (Figure 2a) and BSA:GA (3:1) (Figure 2b) and have order to evaluate the variation of turbidity to fixed $\mathrm{pH}$ and ionic strength, at different $\mathrm{pH}$ along the turbidimetric titration. For BSA:PEC solution, we found a totally cloudy solution from $\mathrm{pH} 3.8$ to 2.7 and from $\mathrm{pH} 4.2$ to 3.4 for BSA:GA similar to the results shown in Figure 1.

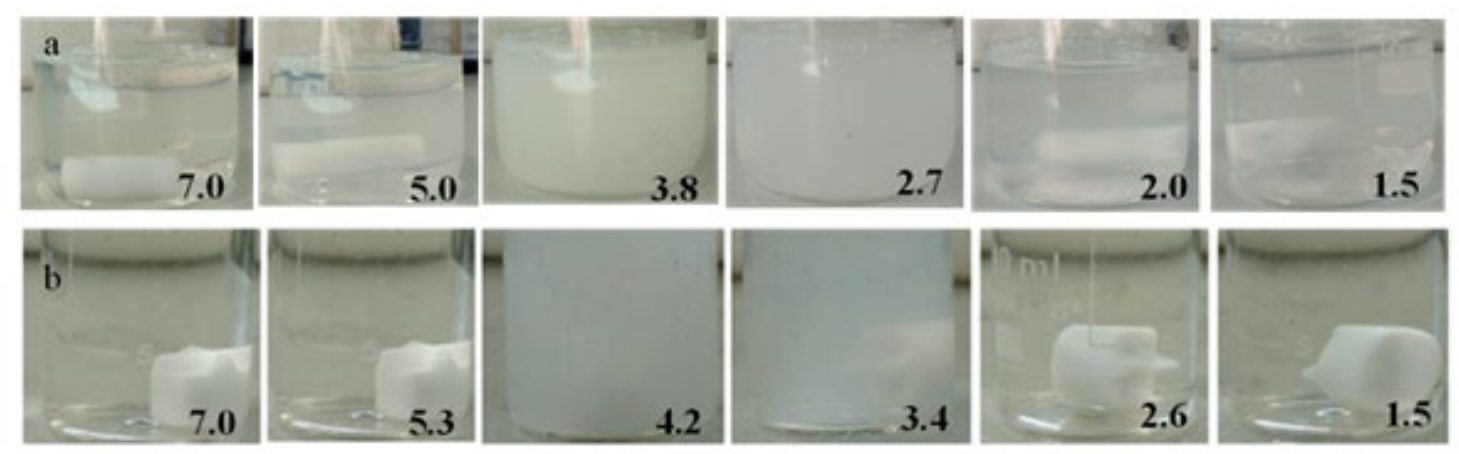

Figure 2. (a) Photographs of solutions containing BSA:PEC (10:1) and (b) BSA:GA (3:1) at different pH.

\subsection{Potencial- $\zeta$}

The potential- $\zeta(\mathrm{mV})$ as a function of $\mathrm{pH}(2.0-7.0)$ was performed to evaluate the charge density of the isolated polymers (BSA, PEC and GA) and the complexes formed at different ratios (r) and the results are shown in Figure 3. According to Figure 3a, BSA showed a positive potential of +26.4 at $\mathrm{pH} 2.0$ and as pH increased, the potential decreased, reaching zero load at $\mathrm{pH} 4.7$, this being its isoelectric point, as reported in the literature, and decreased to $-21.9 \mathrm{mV}$ potential at $\mathrm{pH}$ 7.0. Similar results were found by Santos et al. (2018). In Figure 3a, with respect to PEC as an anionic polysaccharide, it could be showed a negative charge of $\mathrm{pH} 7.0$ at $\mathrm{pH} 2.0$ reaching $-42.1 \mathrm{mV}$ potential at $\mathrm{pH} 7.0$ and potential- $\zeta$ of $-2.1 \mathrm{mV}$ at $\mathrm{pH} 2.0$, as observed by Muhoza et al. (2019). As regards Figure 3b, GA presented a negative charge throughout the studied $\mathrm{pH}$ range reaching a potential- $\zeta$ of $-35.1 \mathrm{mV}$ at $\mathrm{pH} 7.0$ and $-2.7 \mathrm{mV}$ at $\mathrm{pH} 2.0$ similar to that reported by Vinayahan et al. (2010)

In general, the ratio of protein:polysaccharide (r) has a great impact on the degree of complexation. In low ratios (high concentration of polysaccharides), the complexes are highly negative because there are few protein molecules linked to the anionic polysaccharide. As the ratio increases (the polysaccharide concentration decreases), the charge on the complexes becomes less negative due to the higher amount of proteins. Thus the protein becomes available to neutralize the negative charges of the carboxylic groups even when $\mathrm{pH}>\mathrm{pI}$, (Girard et al., 2003) which gradually increases the strength of the interaction between protein and polysaccharide resulting in displacement $\mathrm{pH}_{\varnothing 1}$ and $\mathrm{pH}_{c}$. 
Complexes containing different ratios of BSA:PEC (Figure 3a) and BSA:GA (Figure 3b) showed intermediate zeta potentials and pI's varying from 2.6 to 4.6 and 3.7 to 4.2 , respectively, indicating that the BSA was strongly bound to the polysaccharides and meant that the interaction occurred when the charges between the polymers were opposite, probably through electrostatic interactions between the anionic carboxyl groups of the polysaccharide and the cationic amino groups of BSA (Jones \& Mc Clements, 2010). As the ratio increases, the pI's of the complexes move in a positive direction and the instability increases. It is possible to verify that approximate values of $\mathrm{pI}$ of the mixtures (BSA:PEC and BSA:GA) coincide with the maximum turbidity point observed in Figure 1a indicating that the interaction occurred more intensely when there was load neutrality of the biopolymers (Liu et al., 2015).

The study of coacervate complexes through the analysis of zeta potential had the purpose of identifying the ideal $\mathrm{pH}$ for each ratio (protein: polysaccharide) studied. From these results, it was possible to choose the ratio and the most suitable $\mathrm{pH}$ for the specific conditions of a given product in which it is intended to apply these complexes.
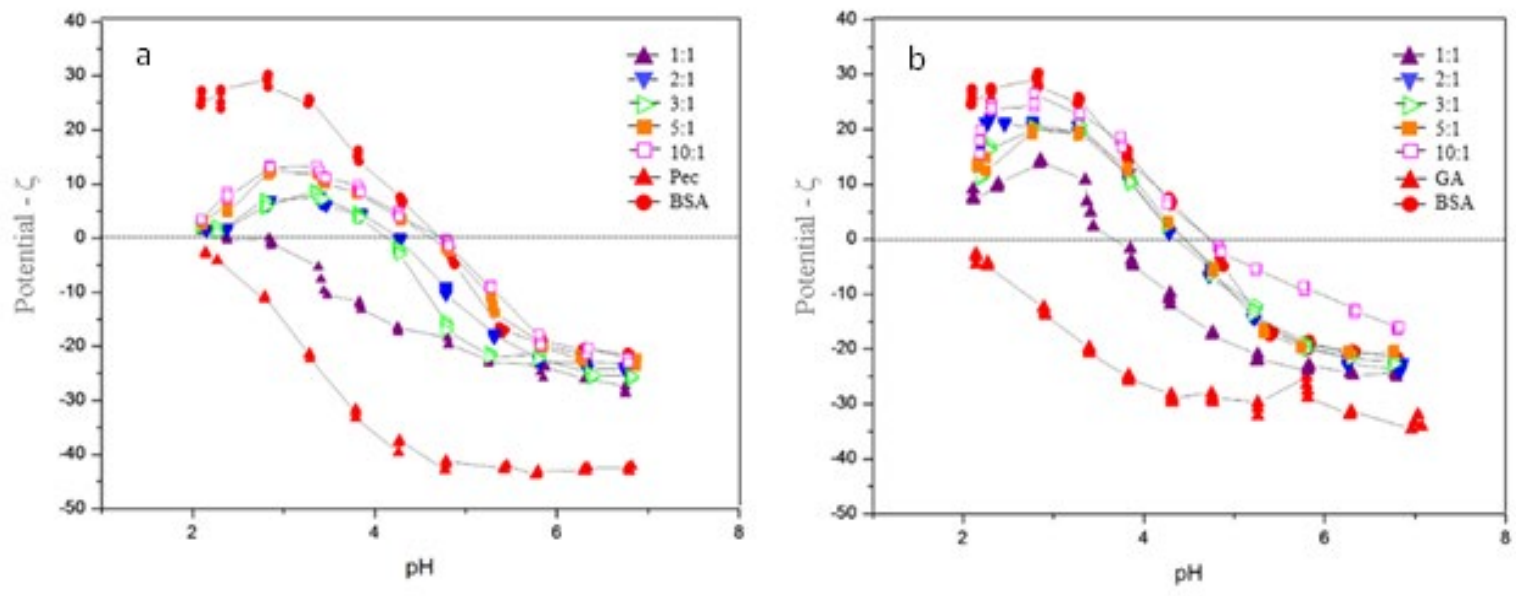

Figure 3. pH-dependent potential of the samples containing (a) PEC and BSA:PEC and (b) GA complexes and BSA:GA complexes in different ratios.

\subsection{Effect of ionic strength on the formation of coacervated complexes}

Figure 4 shows the influence of $\mathrm{NaCl}$ on the formation of coacervate complexes between BSA:PEC (10:1) (Figure 4a) and BSA:GA (3:1) (Figure 4b) by turbidimetric analysis at different concentrations of $\mathrm{NaCl}$. When analyzing Figure 4a concerning the complexes between BSA:PEC, we could see that the turbidity of all curves were practically constant from $\mathrm{pH} 7.0$ to 5.0 and had a low turbidity value until reaching $\mathrm{pH} \varnothing 1$. After this value the turbidity could increase and reach maximum values at all different concentrations of $\mathrm{NaCl}$. However, the turbidity of the systems behaves differently at the salt concentrations studied when $\mathrm{pH}$ decreases from 5.0 to 2.0. At the concentrations of $\mathrm{NaCl} \leq 0.10 \mathrm{~mol} \mathrm{~L}^{-1}$, a shift from $\mathrm{pH}_{\varnothing 1}$ to lower values was observed, whereas $\mathrm{pH}_{\varnothing 2}$ showed no dependence on the $\mathrm{NaCl}$ concentration, as it did not change. At $0.40 \mathrm{~mol} \mathrm{~L}^{-1}$ there is no noticeable increase in turbidity. This is because at this concentration the competitive adsorption capacity between the $\mathrm{Na}^{+}$and $\mathrm{Cl}^{-}$ions becomes sufficiently strong to suppress the electrostatic interaction between the biopolymers, which explains the less turbidity of the system. These results are in agreement with those found by $\mathrm{Li}$ et al. (2012) which at concentrations of $\mathrm{NaCl} \leq 0.2 \mathrm{~mol} \mathrm{~L}^{-1}$ they did not observe reduction in turbidity for BSA and SBP. According to works by Ru et al. (2012) the increase of the salt concentration reduced the range of formation of the complexes, however, it was not verified turbidity reduction in the concentration of $0.40 \mathrm{~mol} \mathrm{~L}^{-1}$ to $5: 1$ ratio. 

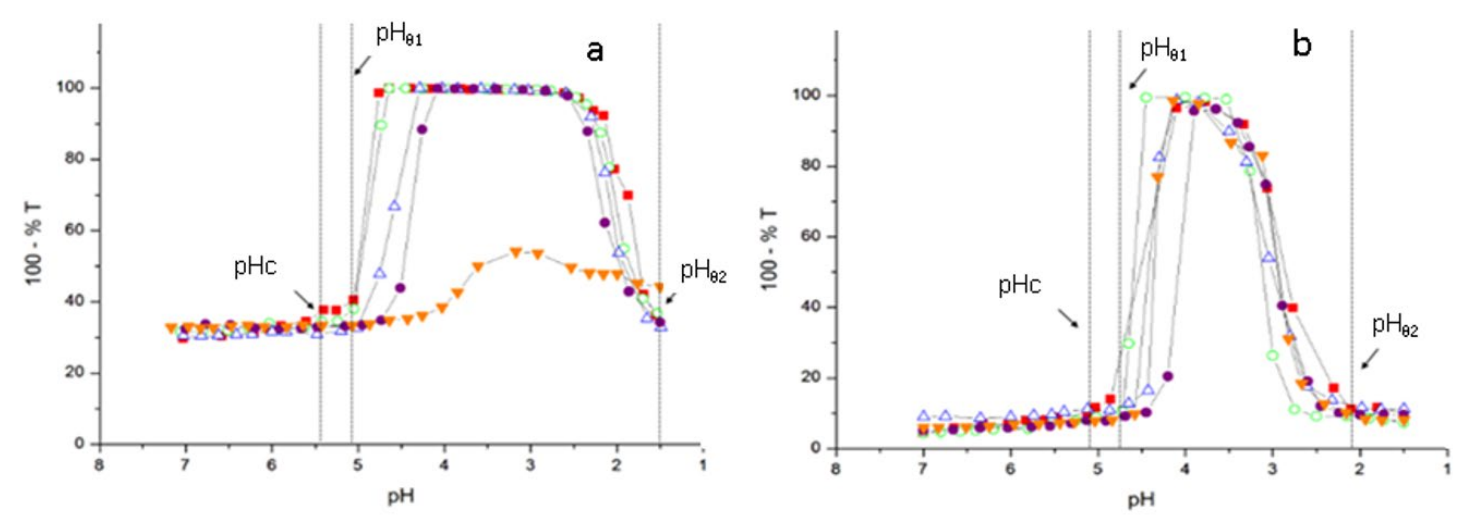

\section{$\square 0.0 \mathrm{~mol} \mathrm{~L}^{-1}, \bigcirc 0.01 \mathrm{~mol} \mathrm{~L}^{-1}, \quad \Delta 0.05 \mathrm{~mol} \mathrm{~L}^{-1}, \quad 0.10 \mathrm{~mol} \mathrm{~L}^{-1}, \quad \nabla \quad 0.40 \mathrm{~mol} \mathrm{~L}^{-1}$}

Figure 4. Influence of different $\mathrm{NaCl}$ concentrations on the turbidity of samples containing (a) BSA:PEC in a ratio of $10: 1$ and (b) BSA:GA in a ratio of $3: 1$.

Contrary to what was observed for the complexes between BSA:PEC, according to Figure $4 \mathrm{~b}$, the formation of complexes between 3:1 BSA:GA ratio was not reduced at the salt concentrations studied. Different results were verified by some authors between GA and different proteins confirming that the sensitivity of the complex to the salt may vary in function of the studied biopolymers, being able to be in conflict with the intermolecular interactions or still to be related to other parameters of the analysis as the type of salt, total concentration and biopolymer ratio (Vinayahan et al., 2010; Weinbreck et al., 2003; Niu et al., 2014).

It can be further noted that when increasing the $\mathrm{NaCl}$ concentration, the $\mathrm{pH}_{\varnothing 1}$ to $\mathrm{pH}_{\varnothing 2}$ range for the BSA:PEC coacervates (Figure 4a) and BSA:GA (Figure 4b) were reduced and this result was also observed by Weinbreck et al. (2003). The change in $\mathrm{pH}_{\varnothing 1}$ dependent on ionic strength is a known phenomenon. In general, the presence of salt in solution weakens the interaction, and may even suppress the formation of coacervate complexes between protein and polysaccharide (Weinbreck et al., 2003). We can attribute the effect caused by $\mathrm{NaCl}$ to the fact that the protein molecules are amphoteric polyelectrolytes, i.e., they are characterized as polymers containing both positive and negative charges, so there are attractive and repulsive electrostatic forces between the charges of proteins and polysaccharides (Hattori et al., 2000). The complexation is driven by electrostatic interactions but is influenced by the entropy of the system which increases due to the expulsion of small ions from the double layers around the chains of individual polyelectrolytes (Biesheuvel \& Stuart, 2004). A large amount of salt hinders the release of these ions, effectively reducing the available active sites for the interaction between the polymers and suppressing the complexation (Espinosa-Andrews et al., 2007). The variation in the salt concentration limit for coacervation may be related to the different natures of the polymers, including differences in charge density due to branching and different pKa values (Priftis et al., 2014).

\subsection{Fourier Transform Infrared spectroscopy (FTIR spectroscopy)}

The FTIR spectra of BSA, PEC and BSA:PEC are shown in Figure 5a and BSA:GA in the Figure 5b. According to the literature, the most sensitive regions of FTIR spectra associated with the structure of BSA refer to amides I, II and III. The major FTIR spectra observed for BSA (Figure 5) are between the bands $1300 \mathrm{~cm}^{-1}$ to $1700 \mathrm{~cm}^{-1}$. The peak observed at $1640 \mathrm{~cm}^{-1}$ represents the amide I being formed by stretching the $\mathrm{C}=\mathrm{O}$ (free carbonyl) group, the $1526 \mathrm{~cm}^{-1}$ peak for the drawing of the $\mathrm{NH}$ groups represents the amide II, and the amide III refers to the $1393 \mathrm{~cm}^{-1}$ peak corresponding to the stretching of the $\mathrm{CN}$ and $\mathrm{NH}$ groups (Stuart, 2006; Huang et al., 
2006). In addition to the amides, the stretching of the N-H and O-H groups near $3300 \mathrm{~cm}^{-1}$ (Barth \& Zscherp, 2002) was verified. A similar BSA profile was also found by Santos et al. (2018).

a

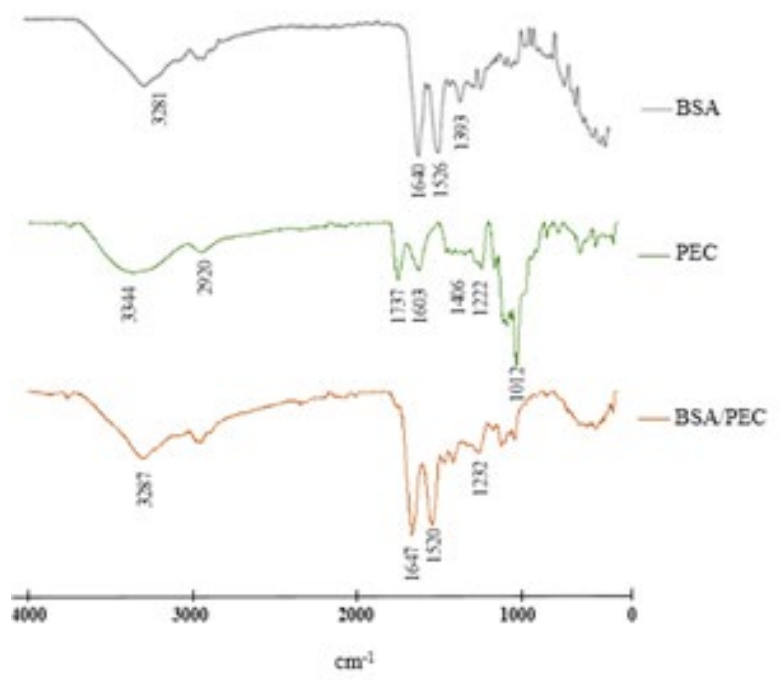

b

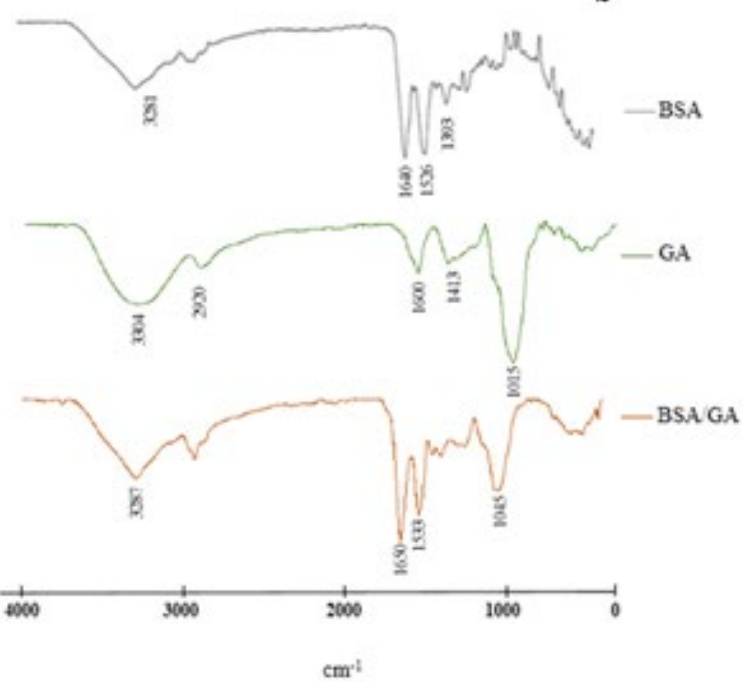

Figure 5. FTIR spectra for (a) BSA, PEC and BSA:PEC (10:1) at pH 4.5 without addition of $\mathrm{NaCl}$ and (b) BSA, GA and BSA:GA (3:1) at $\mathrm{pH} 4.0$ without addition of $\mathrm{NaCl}$.

The FTIR spectrum of PEC depends on the origin of the polysaccharide and the degree of methylation of carboxyl groups. By means of the FTIR spectra presented (Figure 5a), it was possible to identify the axial deformation of $\mathrm{O}-\mathrm{H}$, observed in the intense and very wide band in the region of 3.600 to $3.000 \mathrm{~cm}^{-1}$. The band in the region of $2920 \mathrm{~cm}^{-1}$ is attributed to the vibration of the C-H bonds. The band in the region of $1737 \mathrm{~cm}^{-1}$ corresponds to the axial deformation of the conjugated ester $(\mathrm{C}=\mathrm{O}$ in ester group $)$ and the band at $1603 \mathrm{~cm}^{-1}$ is attributed to the asymmetric deformation of the COO- group. Similar results were also observed by Slavutsky \& Bertuzzi (2019). The carbohydrates have strong absorption between 1200 and $950 \mathrm{~cm}^{-1}$, and this region is associated with the characteristic fingerprint for each polysaccharide. According to Gnanasambandam \& Proctor (2000) these bands are often difficult to interpret. For PEC, this region was identified at the peak at $1012 \mathrm{~cm}^{-1}$, equal to that found by Lan et al. (2020)

As for PEC, a broad and intense band in the region of 3600-3000 $\mathrm{cm}^{-1}$ was observed for the GA sample (Figure 5b) due to the stretching of the $-\mathrm{OH}$ - groups and a $2920 \mathrm{~cm}^{-1}$ peak characteristic of carboxyl groups (negatively charged), is due to the stretching of the $\mathrm{CH}$ group. In $1600 \mathrm{~cm}^{-1}$ the polymers also showed the characteristic band of $\mathrm{C}=\mathrm{C}$ stretch. The band at $1413 \mathrm{~cm}^{-1}$ represents $\mathrm{C}=\mathrm{O}$ symmetric stretching, being in agreement with those found by Daoub et al. (2016). The fingerprint region in GA was located at the peak at $1015 \mathrm{~cm}^{-1}$

According to the results, we found that there were differences between the spectra of the individual biopolymer and the spectra of the complexes, in this sense, we could conclude that there were intermolecular interactions between the carboxyl groups in the structure of the polysaccharides and the functional groups of the protein. When comparing the spectrum of complex coacervates for BSA:PEC (Figure 5a) and BSA:GA (Figure 5b) with the BSA spectrum, we verified a displacement and an increase in the intensity of the bands referring to the amides. The increase in these bands would be related to the occurrence of electrostatic interaction between the amide groups of BSA (NH4 +) and the carboxyl groups of GA and PEC (COO-). Similar results were found by Raei et al. (2018) for WPI and PEC complexes.

In addition, the spectrum of the complexes showed a broad band around 3000-3600 $\mathrm{cm}^{-1}$, indicating an increase of hydrogen bonding. This implies that the hydrogen bonding was also involved in the interaction 
between the biopolymers. The complexes showed a peak in the fingerprint region that could be an overlap of the protein and polysaccharide. In BSA/GA complexes, this peak was much more intense than in BSA/PEC. These results may be associated with the protein: polysaccharide ratio considering that the presence of the polysaccharide in BSA/GA (3:1) was greater than in BSA/PEC (10:1)

The spectra of the complexes reflect the formation of a structure that could exhibit specific spectra of protein as well as of polysaccharides, confirmed the interaction between them through coacervation, but also suggested the type of interactions involved in that process that included hydrogen bonds and electrostatic interactions.

\section{Conclusions}

This study demonstrated that the interaction between BSA and different polysaccharides (PEC and GA) may result in the formation of soluble and insoluble complexes as a function of $\mathrm{pH}$. The presence of $\mathrm{NaCl}$ negatively influenced the formation of the complexes. BSA: PEC complexes were more sensitive to high salt concentrations than BSA: GA. Their formation was also influenced by the ratio having been intensified as a function of the protein increase in the system (BSA:PEC 10:1; BSA:GA 3:1). The PEC exhibited a higher charge density compared to GA which required more positive BSA charge for neutralization and complexation. Through the turbidimetric analysis, it was possible to identify which BSA: GA complexes were formed under specific conditions of $\mathrm{pH}$ (3.5) while BSA: PEC complexes exhibited a behavior that allows their application in different food products (4.9 to 1.5). Observed changes in the spectra (FTIR) of the complexes indicated the participation of hydrogen and electrostatic bonds in their formation. The interaction between proteins and polysaccharides through complex coacervation constitutes a technological alternative, considered a clean technology that does not cause an increase of polluting agents to the environment. The coacervates are attractive to the industry because they are natural products obtained from inexpensive and easily approved ingredients for use in food. Being formed a biopolymer differentiated functional property able to microencapsulate bioactive ingredients.

\section{Acknowledgements}

The authors thank Conselho Nacional de Desenvolvimento Cientifico e Tecnológico - CNPq, Coordenação de Aperfeiçoamento de Pessoal de Nivel Superior - CAPES (Financing Code 001) and Fundação de Amparo à Pesquisa do Estado do Rio de Janeiro - FAPERJ for the financial support.

\section{References}

Anvari, M., Pan, C., Yoon, W., \& Chung, D. (2015). Characterization of fish gelatin-gum arabic complex coacervates as influenced by phase separation temperature. International Journal of Biological Macromolecules, 79, 894-902. PMid:26054661. http://dx.doi.org/10.1016/j.jibiomac.2015.06.004

Aryee, F. N. A., \& Nickerson, M. T. (2012). Formation of electrostatic complexes involving mixtures of lentil protein isolates and gum Arabic polysaccharides. Food Hydrocolloids, 48, 520-527. http://dx.doi.org/10.1016/j.foodres.2012.05.012

Bago Rodriguez, A. M., Binks, B. P., \& Sekine, T. (2018). Emulsion stabilisation by complexes of oppositely charged synthetic polyelectrolytes. Soft Matter, 14(2), 239-254. PMid:29231947. http://dx.doi.org/10.1039/C7SM01845B

Barth, A., \& Zscherp, C. (2002). What vibrations tell us about proteins. Quarterly Reviews of Biophysics, 35(4), 369-430. PMid:12621861. http://dx.doi.org/10.1017/S0033583502003815

Biesheuvel, P. M., \& Stuart, M. A. C. (2004). Cylindrical cell model for the electrostatic free energy of polyelectrolyte complexes. Langmuir, 20(11), 4764-4770. PMid:15969195. http://dx.doi.org/10.1021/la0496789

Daoub, R. M. A., Elmubarak, A. H., Misran, M., Hassan, E. A., \& Osman, M. E. (2016). Characterization and functional properties of some natural acacia gums. Journal of the Saudi Society of Agricultural Sciences, 17(3), 241-249. http://dx.doi.org/10.1016/j.jssas.2016.05.002

Dickinson, E. (2008). Interfacial structure and stability of food emulsions as affected by protein-polysaccharide interactions. Soft Matter, 4(5), 932-942. PMid:32907124. http://dx.doi.org/10.1039/b718319d 
Eghbal, N., \& Choudhary, R. (2018). Complex coacervation: Encapsulation and controlled release of active agents in food systems. LWT, 90, 254-264. http://dx.doi.org/10.1016/j.lwt.2017.12.036

Espinosa-Andrews, H., Baéz-González, J. G., Cruz-Sosa, F., \& Vernon-Carter, E. J. (2007). Gum arabic-chitosan complex coacervation. Biomacromolecules, 8(4), 1313-1318. PMid:17375951. http://dx.doi.org/10.1021/bm0611634

Ganju, S., \& Gogate, P. R. (2017). A review on approaches for efficient recovery of whey proteins from dairy industry effluents. Journal of Food Engineering, 215, 84-96. http://dx.doi.org/10.1016/j.jfoodeng.2017.07.021

Girard, M., Turgeon, S. L., \& Gauthier, S. F. (2003). Thermodynamic parameters of $\beta$-lactoglobulin-pectin complexes assessed by isothermal titration calorimetry. Journal of Agricultural and Food Chemistry, 51(15), 4450-4455. PMid:12848524. http://dx.doi.org/10.1021/jf0259359

Gnanasambandam, R., \& Proctor, A. (2000). Determination of pectin degree of esterification by diffuse reflectance Fourier transform infrared spectroscopy. Food Chemistry, 68(3), 327-332. http://dx.doi.org/10.1016/S0308-8146(99)00191-0

Gulão, E. D. S., Souza, C. J. F., Silva, F. A. S., Coimbra, J. S. R., \& Garcia-Rojas, E. E. (2014). Complex coacervates obtained from lactoferrin and gum arabic: Formation and characterization. Food Research International, 65, 367-374. http://dx.doi.org/10.1016/j.foodres.2014.08.024

Hattori, T., Hallberg, R., \& Dubin, P. L. (2000). Roles of electrostatic interaction and polymer structure in the binding of $\beta-$ lactoglobulin to anionic polyelectrolytes: Measurement of binding constants by frontal analysis continuous capillary electrophoresis. Langmuir, 16(25), 9738-9743. http://dx.doi.org/10.1021/la000648p

Huang, C. Y., Balakrishnan, G., \& Spiro, T. G. (2006). Protein secondary structure from deep-UV resonance Raman spectroscopy. Journal of Raman Spectroscopy, 37(1-3), 277-282. http://dx.doi.org/10.1002/jrs.1440

International Union of Pure and Applied Chemistry - IUPAC. (1997). Compendium of chemical terminology (2nd ed.). Oxford: Blackwell Scientific Publications.

Islam, A. M., Phillips, G. O., Sljivo, A., Snowden, M. J., \& Williams, P. A. (1997). A review of recent developments on the regulatory, structural and functional aspects of gum arabic. Food Hydrocolloids, 11(4), 493-505. http://dx.doi.org/10.1016/S0268-005X(97)80048-3

Jones, O. G., \& McClements, D. J. (2010). Functional biopolymer Particles: Design, fabrication, and applications. Comprehensive Reviews in Food Science and Food Safety, 9(4), 374-397. PMid:33467840. http://dx.doi.org/10.1111/j.15414337.2010.00118.x

Jones, O. G., Decker, E. A., \& Mc Clements, D. J. (2009). Formation of biopolymer particles by thermal treatment of blactoglobulin-pectin complexes. Food Hydrocolloids, 23(5), 1312-1321. http://dx.doi.org/10.1016/j.foodhyd.2008.11.013 Kruif, C. G., \& Tuinier, R. (2001). Polysaccharide protein interactions. Food Hydrocolloids, 15(4-6), 555-563. http://dx.doi.org/10.1016/S0268-005X(01)00076-5

Lan, Y., Ohm, J.-B., Chen, B., \& Rao, J. (2020). Phase behavior, thermodynamic and microstructure of concentrated pea protein isolate-pectin mixture: Effect of pH, biopolymer ratio and pectin charge density. Food Hydrocolloids, 101, 105556. http://dx.doi.org/10.1016/j.foodhyd.2019.105556

Li, X., Fang, Y., Al-Assaf, S., Phillips, G. O., Yao, X., Zhang, Y., Zhao, M., Zhang, K., \& Jiang, F. (2012). Complexation of bovine serum albumin and sugar beet pectin: Structural transitions and phase diagram. Langmuir, 28(27), 10164-10176. PMid:22697399. http://dx.doi.org/10.1021/la302063u

Liu, J., Shim, Y. Y., Wang, Y., \& Reaney, M. J. T. (2015). Intermolecular interaction and complex coacervation between bovine serum albumin and gum from whole flaxseed (Linum usitatissimum L.). Food Hydrocolloids, 49, 95-103. http://dx.doi.org/10.1016/j.foodhyd.2015.02.035

Liu, S., Low, N. H., \& Nickerson, M. T. N. (2009). Effect of pH, salt, and biopolymer ratio on the formation of pea protein isolategum arabic complexes. Journal of Agricultural and Food Chemistry, 57(4), 1521-1526. PMid:19170635. http://dx.doi.org/10.1021/jf802643n

Lv, Y., Yang, F., Li, X., Zhang, X., \& Abbas, S. (2014). Formation of heat-resistant nanocapsules of jasmine essential oil via gelatin/gum arabic based complex coacervation. Food Hydrocolloids, 55, 305-314. http://dx.doi.org/10.1016/j.foodhyd.2013.06.003

Muhoza, B., Xia, S., Cai, J., Zhang, X., Duhoranimana, E., \& Su, J. (2019). Gelatin and pectin complex coacervates as carriers for cinnamaldehyde: Effect of pectin esterification degree on coacervate formation, and enhanced thermal stability. Food Hydrocolloids, 87, 712-722. http://dx.doi.org/10.1016/j.foodhyd.2018.08.051

Niu, F., Su, Y., Liu, Y., Wang, G., Zhang, Y., \& Yang, Y. (2014). Ovalbumin-gum arabic interactions: Effect of pH, temperature, salt, biopolymers ratio and total concentration. Colloids and Surfaces. B, Biointerfaces, 113, 477-482. PMid:24149009. http://dx.doi.org/10.1016/j.colsurfb.2013.08.012

Priftis, D., Xia, X., Margossian, K. O., Perry, S. L., Leon, L., Qin, J., Pablo, J. J., \& Tirrell, M. (2014). Ternary, tunable polyelectrolyte complex fluids driven by complex coacervation. Macromolecules, 47(9), 3076-3085. http://dx.doi.org/10.1021/ma500245j

Raei, M., Rafe, A., \& Shahidi, F. (2018). Rheological and structural characteristics of whey protein-pectin complex coacervates. Journal of Food Engineering, 228, 25-31. http://dx.doi.org/10.1016/j.jfoodeng.2018.02.007

Ru, Q., Wang, Y., Lee, J., Ding, Y., \& Huang, Q. (2012). Turbidity and rheological properties of bovine serum albumin/pectin coacervates: Effect of salt concentration and initial protein/polysaccharide ratio. Food Hydrocolloids, 88, 838-846. http://dx.doi.org/10.1016/j.carbpol.2012.01.019 
Santos, M. B., Carvalho, C. W. P., \& Garcia-Rojas, E. E. (2018). Heteroprotein complex formation of bovine serum albumin and lysozyme: Structure and thermal stability. Food Hydrocolloids, 74, 267-274. http://dx.doi.org/10.1016/j.foodhyd.2017.08.016

Santos, M. B., Carvalho, C. W. P., \& Garcia-Rojas, E. E. (2021). Microencapsulation of vitamin D3 by complex coacervation using carboxy- methyl tara gum (Caesalpinia spinosa) and gelatin A. Food Chemistry, 343, 128529. PMid:33191011. http://dx.doi.org/10.1016/j.foodchem.2020.128529

Silva, K. S., Fonseca, T. M. R., Amado, L. R., \& Mauro, M. A. (2018). Physicochemical and microstructural properties of whey protein isolate-based films with addition of pectin. Food Packaging and Shelf Life, 16, 122-128. http://dx.doi.org/10.1016/j.fpsl.2018.03.005

Silva, M. C., \& Andrade, C. T. (2009). Evaluating conditions for the formation of chitosan/gelatin microparticles. Polímeros, 19(2), 133-137. http://dx.doi.org/10.1590/S0104-14282009000200010

Slavutsky, A. M., \& Bertuzzi, M. A. (2019). Formulation and characterization of hydrogel based on pectin and brea gum. International Journal of Biological Macromolecules, 123, 784-791. PMid:30414901. http://dx.doi.org/10.1016/j.ijbiomac.2018.11.038

Souza, C. J. F., Costa, A. R., Souza, C. F., Tosin, F. F. S., \& Garcia-Rojas, E. E. (2018a). Complex coacervation between lysozyme and pectin: Effect of $\mathrm{pH}$, salt, and biopolymer ratio. International Journal of Biological Macromolecules, 107(Pt A), 1253-1260. PMid:29017886. http://dx.doi.org/10.1016/j.ijbiomac.2017.09.104

Souza, C. J. F., Garcia-Rojas, E. E., \& Favaro-Trindade, C. S. (2018b). Lactase ( $\beta$-galactosidase) immobilization by complex formation: Impact of biopolymers on enzyme activity. Food Hydrocolloids, 83, 88-96.

http://dx.doi.org/10.1016/j.foodhyd.2018.04.044

Souza, C. J. F., Garcia Rojas, E. E., Melo, N. R., Gaspar, A., \& Lins, J. F. C. (2013). Complex coacervate obtained from interaction egg yolk lipoprotein and polysaccharides. Food Hydrocolloids, 30(1), 375-381.

http://dx.doi.org/10.1016/j.foodhyd.2012.06.012

Stuart, B. H. (2006). Infrared spectroscopy of biological applications: An overview. In R. A. Meyers (Ed.), Encyclopedia of analytical chemistry. Chichester: John Wiley \& Sons. http://dx.doi.org/10.1002/9780470027318.a0208

Timilsena, Y. P., Akanbi, T. O., Khalid, N., Adhikari, B., \& Barrow, C. J. (2019). Complex coacervation: Principles, mechanisms and applications in microencapsulation. International Journal of Biological Macromolecules, 121, 1276-1286. PMid:30352231. http://dx.doi.org/10.1016/j.ijbiomac.2018.10.144

Tolstoguzov, V. B. (1991). Functional properties of food proteins and role of protein polysaccharide interaction. Food Hydrocolloids, 4(6), 429-468. http://dx.doi.org/10.1016/S0268-005X(09)80196-3

Turgeon, S. L., Beaulieu, M., Schmitt, C., \& Sanchez, C. (2003). Protein-polysaccharide interactions: Phase-ordering kinetics, thermodynamic and structural aspects. Current Opinion in Colloid \& Interface Science, 8(4-5), 401-414. http://dx.doi.org/10.1016/S1359-0294(03)00093-1

Vinayahan, T., Williams, P. A., \& Phillips, G. O. (2010). Electrostatic interaction and complex formation between gum arabic and bovine serum albumin. Biomacromolecules, 11(12), 3367-3374. PMid:21067247. http://dx.doi.org/10.1021/bm100486p

Weinbreck, F., De Vries, R., Schrooyen, P., \& De Kruif, C. G. (2003). Complex coacervation of whey proteins and gum arabic. Biomacromolecules, 4(2), 293-303. PMid:12625724. http://dx.doi.org/10.1021/bm025667n

Yang, S., Li, X., Hua, Y., Chen, Y., Kong, X., \& Zhang, C. (2020). Selective complex coacervation of pea whey proteins with chitosan To purify main 2S albumins. Journal of Agricultural and Food Chemistry, 68(6), 1698-1706. PMid:31986048. http://dx.doi.org/10.1021/acs.jafc.9b06311

Zhao, Y., Li, F., Carvajal, M. T., \& Harris, M. T. (2009). Interactions between bovine serum albumin and alginate: An evaluation of alginate as protein carrier. Journal of Colloid and Interface Science, 332(2), 345-353. PMid:19150078.

http://dx.doi.org/10.1016/j.jcis.2008.12.048

Funding: Ministério da Ciência, Tecnologia e Inovação/Conselho Nacional de Desenvolvimento Científico e Tecnológico, Coordenação de Aperfeiçoamento de Pessoal de Nível Superior e Fundação Carlos Chagas Filho de Amparo à Pesquisa do Estado do Rio de Janeiro. 